\title{
Comparison between the euglycemic- hyperinsulinemic clamp and the use of proxies for determination of insulin sensitivity in horses
}

\author{
Johan Bröjer ${ }^{1 *}$, Sanna Lindåse ${ }^{1}$, Cecilia Müller ${ }^{2}$, Katarina Nostell ${ }^{1}$ \\ From Animal Obesity - causes, consequences and comparative aspects \\ Uppsala, Sweden. 14-16 June 2015
}

\section{Background}

Accurate quantification of insulin resistance is important for diagnosing and determining the efficacy of treatment in patients with equine metabolic syndrome (EMS). The euglycemic-hyperinsulinemic clamp (EHC) is a goldstandard method for measuring insulin sensitivity (IS) but the complexity of the technique limits its use in research. The use of proxies based on fasting values offers an attractive alternative.

\section{Objectives}

To evaluate the validity of proxies calculated from basal plasma glucose and insulin concentrations that predict insulin sensitivity measured with the EHC in the horse.

\section{Material and methods}

The EHC was conducted in 29 horses of different breeds with a wide range of IS including 12 patients diagnosed with EMS. Basal plasma and insulin concentrations were determined from blood samples collected prior to the EHC. In addition, the ability of proxies to detect changes in IS during a weight gain study in nine Standardbred horses was also included.

\section{Results}

Insulin sensitivity indexes calculated from the EHC (M-value and M/I-value) were correlated ( $\mathrm{r} 2=0.47-$ $0.71)$ to quantitative insulin sensitivity check index (QUICKI) and to the reciprocal of the square root of insulin (RISQI) as well as to the homeostatic model assessment of insulin resistance (HOMA-IR). The proxies

\footnotetext{
* Correspondence: johan.brojer@slu.se

'Department of Clinical Sciences, Swedish University of Agricultural Sciences, Uppsala, Sweden

Full list of author information is available at the end of the article
}

were unable to accurately predict changes in IS during the weight gain study.

\section{Conclusion}

Proxies for screening of IS in the horse may be useful but their ability to detect diet-induced variations in IS appears to be limited.

\section{Authors' details}

'Department of Clinical Sciences, Swedish University of Agricultural Sciences, Uppsala, Sweden. ${ }^{2}$ Department of Animal Nutrition and Management, Swedish University of Agricultural Sciences, Uppsala, Sweden.

Published: 25 September 2015

doi:10.1186/1751-0147-57-S1-03

Cite this article as: Bröjer et al: Comparison between the euglycemichyperinsulinemic clamp and the use of proxies for determination of insulin sensitivity in horses. Acta Veterinaria Scandinavica 2015 57(Suppl 1):O3.
Submit your next manuscript to BioMed Central and take full advantage of:

- Convenient online submission

- Thorough peer review

- No space constraints or color figure charges

- Immediate publication on acceptance

- Inclusion in PubMed, CAS, Scopus and Google Scholar

- Research which is freely available for redistribution
() Biomed Central 